\title{
The Abundance of Gonyaulax polygramma and Chaetoceros sp. Causing Blooming in Ambon Bay, Maluku
}

\author{
Irma Kesaulya ${ }^{1 *}$, Delta R. Rumohoira ${ }^{1}$, A. Saravanakumar ${ }^{2}$ \\ ${ }^{1}$ Marine Science Department, Faculty of Fisheries and Marine Science, Pattimura University \\ Kampus Poka Jl. Martha Alfons-Poka 97233. Ambon-Maluku, Indonesia \\ ${ }^{2}$ Centre of Advanced Study in Marine Biology, Faculty of Marine Science, Annamalai University \\ Parangipettai - 608 502, Cuddalore Dt., Tamilnadu, India \\ *Email: irkesaulya@gmail.com
}

\begin{abstract}
This study examines the first occurrence of non-toxic dinoflagellate blooming of Gonyaulax polygramma and Chaetoceros sp in Ambon Bay that occurred for almost three weeks in January 2019 and it caused the watercolor became red brown. The objective of this study was to identified phytoplankton species and their abundance that cause red tide in the Inner Ambon bay. Phytoplankton samples were collected, temperature, salinity and Secchi depth were measured simultaneously on the $11^{\text {th }}$ and $21^{\text {st }}$ January 2019 (nortwest monsoon) at fifteen sampling stations in Inner Ambon Bay. The results show that the maximum abundance of G. polygramma, Chaetoceros affinis, C. danicus and C. decipiens were found in the greatest concentration up to $20 \times 10^{9}, 9.0 \times 10^{6}, 5.8 \times 10^{6}$ and $3.8 \times 10^{5}$ cells. $L^{-1}$, respectively. They were found either in the form of a single cell or in chains. The very high abundance of cells of those species made the waters become red brown but there was no reports of fish killed during this red tide phenomena. This is the first time report of blooming phytoplankton Gonyaulax polygramma, Chaetoceros affinis, C. danicus and C. decipiens occurred in Ambon bay during the dry season where the recorded waters temperature and salinity ranged from $30-32^{\circ} \mathrm{C}$ and $29-33 \mathrm{psu}$, respectively and the secchi depths ranged from 2 to $6 \mathrm{~m}$. These results show this is the first report of the red tide phenomena in the Inner Ambon bay during the dry season and it occurred for a long period caused by combination of the high abundance of G. polygramma Stein, Chaetoceros affinis, C. danicus and C. decipiens.
\end{abstract}

Keywords: Ambon Bay, blooming, Chaetoceros sp, Gonyaulax polygramma, red tide

\section{Introduction}

Scientific studies indicate that red tide phenomena are caused by phytoplankton blooming in coastal regions throughout the world and its occurrence has increased from time to time in different parts of the ocean around the word. Over several decades, coastal regions have experienced increasing incidences of blooms that are toxic or otherwise harmful (Hallegraeff, 1993; Steidinger et al., 1999; Anderson, 1997; Pan et al., 2001; Anderson et al., 2002; Koochaknejad et al., 2016). Phytoplankton bloom can discolour the water making them appear red when the density of the cells is much higher than in normal conditions and according to Chen et al. (2003) when the concentration of chlorophyll-a reaches more than

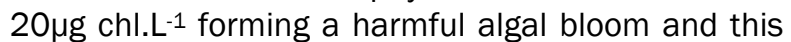
impacts on commercial and recreational interests in the affected regions as well as health issues. Even when these harmful algae blooms (HABs) are formed by species that are not toxic, they can be harmful if their dissipation and senescence depletes the oxygen in the water, leading to massive fish mortality and other important species (Ambariyanto, 2017).

Bloom events in Ambon Bay have been recorded since 1996. The first report of phytoplankton blooming caused by Pyrodinium bahamense which caused the death of three people and several people were taken to hospital after eating shellfish (Wiadnyana et al., 1996), followed by the blooming of Alexandrium affini in Ambon Bay in 1997 (Wagey et al., 1998), and the bloom of the Pyrodinium bahamense (Likumahua, 2013) combined with Alexandrium affine, Ceratium tripos and Tricodesmium thiebautii occurred in 2012 (Lumapuy, 2013) that caused massive fish deaths in a floating fish cage. The blooming events in Ambon Bay reported occurred during the wet season, between May and July when the upwelling occurs in the Banda Sea and brings waters that are rich in nutrients into the Ambon Bay. At the same time, the anthropogenic materials come along with the river runoff into the waters of the Inner Ambon Bay. Eutrophication has been reported as one of the causes in the occurrence of phytoplankton blooming 
in several areas (Holligan, 1985; Heisler et al., 2008; Anderson, 2012). Although nutrient enrichment of estuary and coastal waters seems to be a key factor explaining the development of phytoplankton blooms (Valiela et al., 1997; Teichberg et al., 2010; Smetacek and Zingone, 2013), the extent, distribution, and species composition of blooms vary greatly among systems of similar nutrient load, which compromises our ability to predict such events based on information about nutrient status alone (Gemilang et al., 2019). Other factors such as climate change have been reported as a trigger for the bloom of phytoplankton.

Interestingly, blooms of Gonyaulax polygramma Stein, Chaetoceros affinis, C. danicus and $C$. decipiens in early January until end of January 2019, was the first time this occurred in Ambon Bay waters during the dry season. Gonyaulax polygramma Stein is marine dinoflagellate and shows wide geographic distribution from cold temperate to tropical waters (Steidinger and Tangen, 1996) and it is considered a warm-temperate to tropical species with a preference for a neritic water. The species that caused the red tide in Japanese waters were the hydrographical data suggested that little rainfall, high water temperature and low water exchange rate enhanced the initial occurrence and the long duration of the red tide (Fukuyo et al., 1991; Koizumi et al., 1996), in Kamaishi bay, Iwate Prefecture Japan (Susilaningsih, 2014), in Jakarta Bay in 1992 and 1993 (Adnan, 1994), in the Yeozu waters of the south sea of Korea (Cho, 2005), in Chabahar coastal waters, North of Gulf of Oman (Koochakneja et al., 2016) and in the shelf waters off Mangarole - South Eastern Arabian Sea (Padmakumar et al., 2018).

Ambon Bay is in an area connected to the Banda Sea. It is a semi-closed water area, and it consists of the Inner Ambon Bay (maximum depth \pm $40 \mathrm{~m})$ and the Outer Ambon Bay (>300m). The inner and the outer parts of the bay are separated by a narrow and shallow sill $( \pm 12 \mathrm{~m})$. The Inner Ambon bay is a neritic semi-closed waters and during a dry season (northwest monsoon) its water temperature is higher than other seasons and the diffusion process of the heat in the surface that causes the mixing phenomenon occurs (Saputra and Lekalette, 2016). The phytoplankton blooming in these waters have been reported to occur during the rainy season when the nutrient concentration increases as a result of anthropogenic pressure. In this season, a big volume of water from the land enters the Ambon Bay through the run-off that causes eutrophication.

This report describes the most recent phytoplankton bloom by Gonyaulax polygramma combined with Chaetoceros sp. that caused red tide during the dry season in the Ambon Bay. The present study aimed to provide information the species composition and their abundance that caused red tide in the Inner Ambon Bay and clues as to why the first blooms arose in Ambon Bay during the dry season based on its temperature and salinity conditions.

\section{Materials and Methods}

Ambon Bay (Figure 1.) consists of the Inner Ambon Bay (IAB) with the average depth is $\pm 25 \mathrm{~m}$ and the Outer Ambon Bay (OAB) with depth more than $300 \mathrm{~m}$. The $I A B$ and $O A B$ are separated by $a$ shallow sill $( \pm 12 \mathrm{~m})$. The Inner Ambon bay is a neritic semi-closed waters and during a dry season (northwest monsoon) its water temperature is higher than other seasons and the diffusion process of the heat in the surface that caused mixing phenomenon occurs (Saputra and Lekalette, 2016). Sampling was carried out at fifteen stations in the Inner Ambon Bay which is in the northern part of Ambon Bay (Figure 1.) where the bloom areas could be seen clearly. The red tide did not appear in the whole surface water of the IAB but it was patch in particular areas. Therefore, the purposive random sampling was implemented in choosing the sampling stations at the first sampling on $11^{\text {th }}$ January. The position of each station was identified by using Global Positioning System (GPSMap 64s Garmin). The second sampling on $21^{\text {nd }}$ of January 2019, was done from the same stations as the previous sampling. The position of the sampling stations can be seen in Figure 1.

Phytoplankton sample were collected by using a $20 \mu \mathrm{m}$ mesh phytoplankton net. The filtered water sample were taken and poured into the sample bottle, fixed immediately onboard with Lugol's iodine solution and 4\% formaldehyde (Sournia, 1978) and taken to the laboratory. All samples were kept inside the boxes and placed in the laboratory with a room temperature of $20^{\circ} \mathrm{C}$. For quantitative analysis of phytoplankton, $1 \mathrm{ml}$ of regular samples was dispensed onto Sedgewick-Rafter counting chamber and counts of the dominant phytoplankton species were recorded at 200x magnification using an inverted Carl Zeiss phase-contrast microscope (10x20) with a digital camera Konus (8.1 MP) attached was used for recording phytoplankton cell images. Species identification was done by using standard manual (Tomas, 1997). At each sampling site, physical parameters were measured prior to sampling. Sea surface temperature $(0.25 \mathrm{~m})$ was recorded onboard using mercury thermometer of accuracy $\pm 0.1^{\circ} \mathrm{C}$, while salinity and transparency was measured using refractometer and Secchi disk (Q 25cm), respectively. 


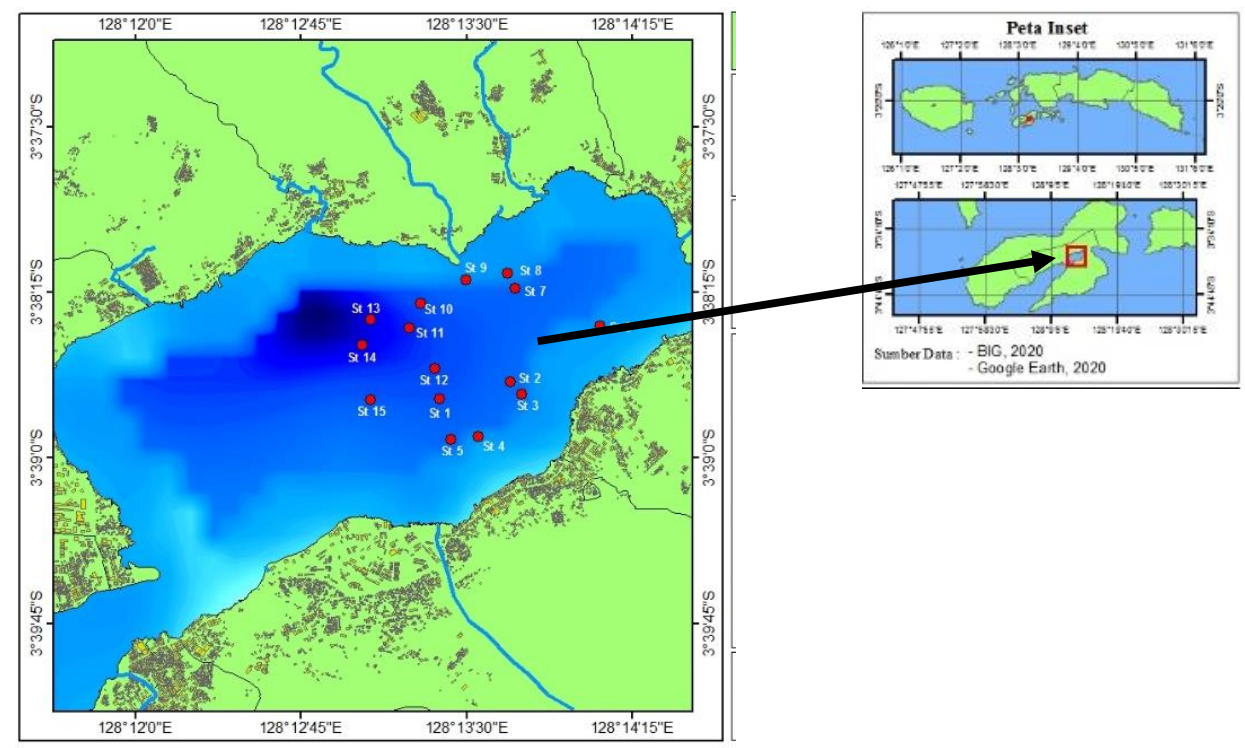

Figure 1. Sampling station in the Inner Ambon Bay. Red dots indicate the station

\section{Result and Discussion}

Four phytoplankton species were found as the main cause of red tide in the Inner Ambon Bay. This red tide phenomenon in the Inner Ambon Bay was clearly notified because a bright sunny day with calm sea for almost three weeks during the dry season in January 2019 (Figure 2a.). The hydrological data during the red tide in the Inner Ambon Bay can be seen on the table 1 . The range of salinity values (30$33 p s u)$ were in the range of salinity reported by Saputra and Lekalette (2016) but the average temperature recorded during the study was $31.08 \pm 0.6^{\circ} \mathrm{C}$, which was higher than the temperature during the northwest season reported by Saputra and Lekalette (2016). The salinity figures recorded were high because of dry season and the Secchi depth was very shallow ranged between 2-6 $m$ because of the high abundance of the phytoplankton cell.

The difference in water colour could be seen clearly on the bright sunny day with a calm sea during this study (Figure 2b.) and it caused by the bloom of Gonyaulax polygramma, Chaetoceros affinis, $C$. danicus and $C$. decipiens that was interestingly the first occurrence in the waters of Ambon Bay. Seawater appeared brownish and consisted of suspended matter. Gonyaulax polygramma formed single cell and large colonies and mostly of Chaetoceros affinis, C. danicus and C. decipiens formed chain that consisted of more than three cells. It is assumed that the high concentration of cells embedded in mucopolysaccharide matrix generated during colony formation and the mucus can be seen drifting on the surface waters. The same situation was also found when blooming of Phaeocystis globosa occurred in the coastal zones of the North Sea (van Rijssel et al., 2000). The secretion of mucus by the high density of cell makes the water become like "juice" and this may contribute to changes in viscosity independent of temperature and salinity (Kesaulya, 2008; Kesaulya et al., 2008).

The phenomena of the red tide has been occurring in Ambon Bay since 1994 and that was the first report of species that caused red tide, Pyrodinium bahamense var compressum. All the previous reports on blooming events in Ambon Bay recorded to appear during the monsoon wet season between May and July in response to nutrient input from terrestrial run-off and the upwelling occurs in the Banda Sea brought waters rich of nutrient flow to the Ambon Bay. During the period of this study, there was a shortage of precipitation according to weather conditions (data not shown) indicating that rain was not sufficient to support the input of nutrient through the run-off the river to the surface waters of the Inner Ambon Bay. However, the concentration of phosphate and nitrate in the IAB was higher than the standard concentration states by ASEAN Marine Water Quality (Anonimous, 2008) or it is in the condition of eutrophication. Gonyaulax

Tabel 1. Physical environmental condition during the red tide in the Inner Ambon bay, January 2019

\begin{tabular}{ll}
\hline Parameter & Value \\
\hline Salinity & $29-33 \mathrm{psu}$ \\
Temperature & $30-32^{\circ} \mathrm{C}$ \\
Depth & $1-8 \mathrm{~m}$ \\
\hline
\end{tabular}


polygramma and Chaetoceros sp. are considered warm-temperate to tropical species with a preference in the neritic waters. According to Reid et al. (1970) it blooms during calm and warm weather during upwelling season, which almost the same condition states by Koizumi et al. (1996) that little rainfall, high water temperature and a low water exchange rate enhanced the initial occurrence and long duration of the red tide of G. polygramma in Uwajima Bay, Japan, in 1994.

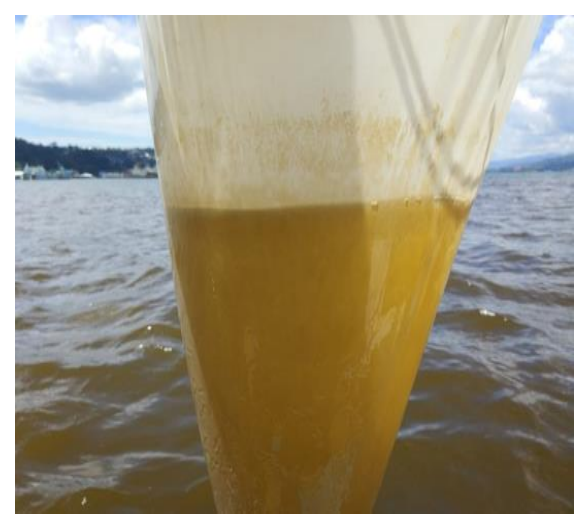

Blooms of G. polygramma (Figure 3a.) and Chaetoceros affinis (Figure 3b.), C. danicus (Figure 3c.) and C. decipiens (Figure 3d.) presented as a dense patch in the Inner Ambon Bay for about three weeks during the dry season of 2019. The high cell density caused the red brown colour of the sea surface. G. polygramma was mainly observed as a single cell (Figure 4a.) and Chaetoceros sp. was mainly in chains usually consisting of more than three cells (Figure 4b-d.).

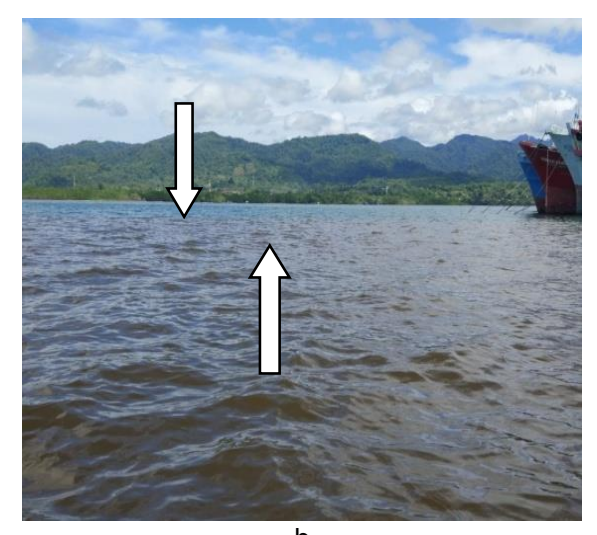

b

Figure 2. Deep-red brown colored (a) that makes the different color as a result of blooming of G. polygramma and Chaetoceros $s p$ in the Inner Ambon Bay (b).

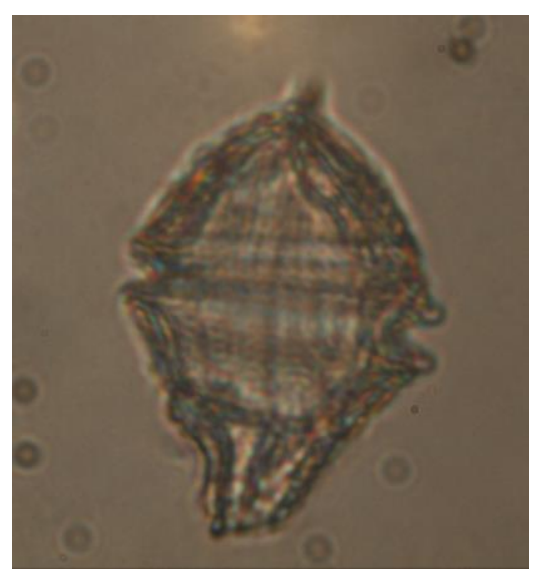

a

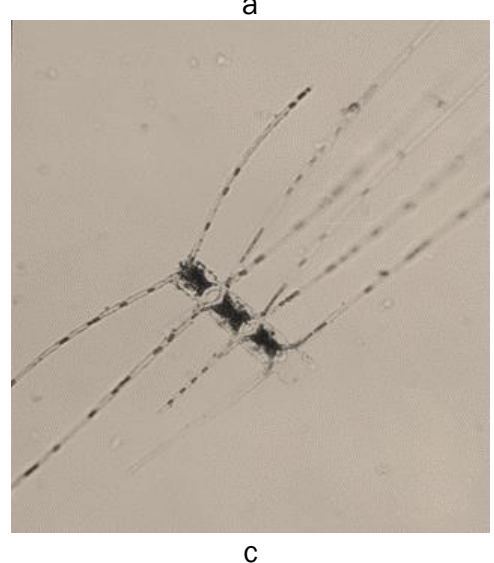

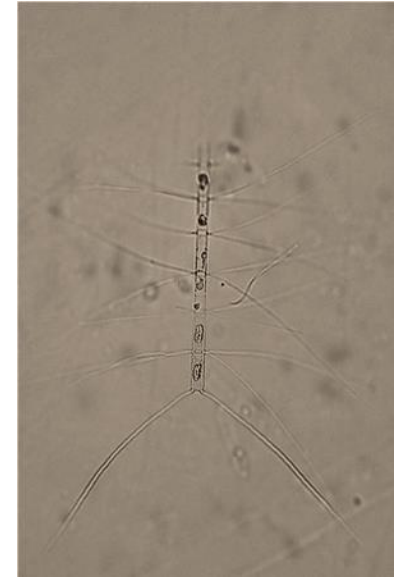

b

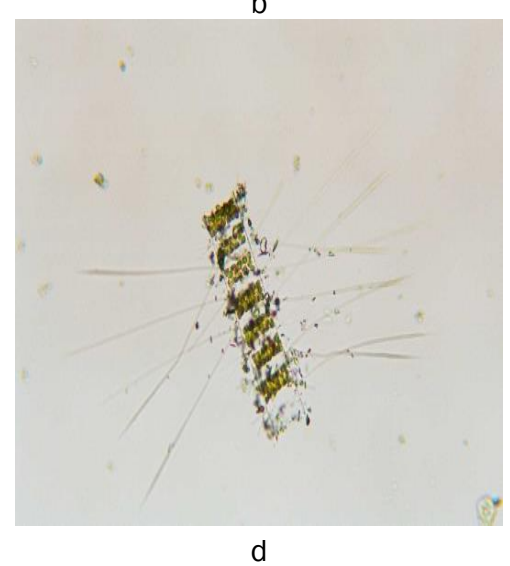

Figure 3. a. Gonyaulax polygramma, b. Chaetoceros affinis, c. Chaetoceros danicus and d. Chaetoceros decipiens 
Along with the Gonyaulax polygramma cells, the bloom also contains their cysts in the germination stage.

Gonyaulax polygramma Stein and Chaetoceros sp were found in very high abundance. The bloom area observed almost a complete exclusion of zooplankton, very few copepods were identified in the whole sample. The abundance of Gonyaulax polygramma ranged from $3.4 \times 10^{5}$ $2.1 \times 10^{9}$ cells. $L^{-1}$, Chaetoceros decipiens ranged from $1.9 \times 10^{4}-9.0 \times 10^{6}$ cells. $L^{-1}$, Chaetoceros affinis ranged from $4.7 \times 10^{4}-5.8 \times 10^{6}$ cells. $L^{-1}$ and Chaetoceros danicus ranged from $1.2 \times 10^{4}-3.8 \times 10^{5}$ cells. $\mathrm{L}^{-1}$, although the abundance were very high of each species as mention above, no records of poisonings or toxins were made. People were still consuming the fish caught from the $I A B$ and there were not any reports of fish deaths in the floating cage around the waters of IAB. The harmful effect from the bloom of Gonyaulax polygramma Stein is often associated with oxygen depletion because of the decay of massive cells bloom and the release of ammonia and sulfide with the cell wall decomposition (Hallegraeff, 1993; Koizumi et al., 1996), which it is not the case during its bloom in the Inner Ambon Bay.

Several studies show that growth of Chaetoceros spp. was enhanced under conditions of high temperature and this was also observed during this study with water temperatures ranging from 30$32^{\circ} \mathrm{C}$. This result agreed well with the studies of Sigaud and Aidar (1993) who found that Chaetoceros sp. had a maximum growth rate at $31^{\circ} \mathrm{C}$. Furthermore, Hemalatha et al. (2012) reported that Chaetoceros simplex reached its highest cell density at $29^{\circ} \mathrm{C}$, and for Chaetoceros spp. cell density increased after an of the phosphorous concentration (Song 2010) as well as dissolved silicate (DSi), dissolved inorganic nitrogen (DIN), dissolved inorganic phosphorous (DIP) (Somsap et al., 2015). With the eutrophication that already exist in the IAB and combined with the calm and warms waters during the dry season January 2019 might be a trigger for the bloom of Gonyaulax polygramma and other four species of Chaetoceros.

\section{Conclusion}

Red tide that occurred in the Inner Ambon bay during the dry season caused the high abundance of Gonyaulax polygramma Stein, Chaetoceros affinis, C. danicus and $C$. decipiens. This red tide phenomena, has been registered as the most intense and occurred for a long period, which has not been reported before.

\section{Acknowledgement}

The authors are grateful to the students of Marine Science Department for helping us in the field and also Dr. Gino Limmon for allowing us using a speed boat during the sampling. This research did not receive any specific grant from funding agencies in the public, commercial, or not-for-profit sectors.

\section{References}

Adnan, Q. 1994. Tiga tahun kejadian Red Tide di Teluk Jakarta. Dalam: Setiapermana, D., Sulistijo, H.P. Hutagalung (eds.). Prosiding seminar pemantauan pencemaran laut 7-9 Februari 1994. 2(3): 109-119.

Ambariyanto. 2017. Conserving endangered marine organisms: causes, trends and challenges. In IOP Conference Series: Earth and Environmental Science. 55(1): 012002. IOP Publishing

Anderson, D.M. 2012. HABs in a changing world: a perspective on harmful algal blooms, their impacts, and research and management in a dynamic era of climactic and environmental change. In: Kim H., Reguera B., Beardsley, R. C., et al. Lagrangian flow observations in the East China, Yellow and Japan Seas. La Mer, 30.

Anderson, D.M. 1997. Bloom dynamics of toxic Alexandrium species in the northeastern U.S. Limnol. Oceanogr. 42: 1009-1022. https://doi.org/ 10.4319/lo.1997.42.5_part_2.1009

Anderson, D.M., Glibert, P.M. \& Burkholder, J.M., 2002. Harmful algal blooms and eutrophication: nutrient sources, composition and consequences. Estuaries 25: 562-584. https://doi.org/10.1007/BF02804901

Anonimous. 2008. Marine Water Quality Management Guidelines and Monitoring Manual. Jakarta: Public Affairs Office.

Chen, C., Zhu, J., Beardsley, R.C. \& Franks, P.J.S. 2003. Physical-biological sources for dense algal blooms near the Changjiang River. Geophys. Res. Lett, 30(10): 1515-1518. https://doi.org/10.1029/2002GL016391

Cho, E.S. 2005 First report on Gonyaulax polygramma (Gonyaulacales, Dinyphyceae) blooms in the Yeozu waters of the sout sea of Korea. J. Environ. Sci., 14(7): 639-647.

Fukuyo, Y. \& Borja V.M. 1991. Marine dinoflagellates in the Philippines. Asian Natural Science Centre, Tokyo: 34pp. 
Gemilang, W.A., Wisha, U.J. \& Dhiauddin, R. 2019. The Importance of Nutrients Concentration Monitoring in Coastal Area. IImu Kelautan: Indonesian Journal of Marine Sciences, 24(2): 69-80. doi: 10.14710/ik.ijms.24.2.69-80

Hallegraeff, G.M. 1993. A review of harmful algal blooms and their apparent global increase. Phycologia 32: 79-99. https://doi.org/10.2216/ i0031-8884-32-2-79.1

Heisler, J., Glibert, P. M., Burkholder J.M., Anderson, D.M., Cochlan, W., Dennison W.C., Dortch Q., Gobler C.J., Heil C.A., Humphrie E., Lewitus A., Magnien R., Marshall H.D., Sellner K., Stckwell D.A., Stoecker DK. \& Suddleson, M. 2008. Eutrophication and harmful algal blooms: a scientific consensus. Harmful Algae, 8: 3-13. https://doi.org/10.1016/j.hal.2008.08.006

Holligan, P.M. 1985. Marine dinoflagellate bloomsgrowth strategies and environmental exploitation. In: Anderson DM., White AW. And Baden DG (Eds.). Toxic Dinoflagellates. Elsevier, New York, USA :133-139.

Kesaulya I. 2008. Coupling of biological and physical parameters in two dimensional microscales phytoplankton distributions. Thesis. School of Biological Sciences, Flinders University, Adelaide.

Kesaulya, I., Leterme, S.C., Mitchell, J.G. \& Seuront, L. 2008. The Impact of turbulence and phytoplankton dynamics on foam formation, seawater viscosity and chlorophyll concentration in the Eastern English Channel. Oceanologia, 50(1): 1-16.

Koizumi, Y., Kohno, J., Matsuyama, N., Uchida T. \& Hanjo, T. 1996. Environmental features and the mass mortality of fish and shellfish during Gonyaulax polygramma red tide occurred in the around Uwajima Bay, Japan, in 1994. Nip. Suisan Gakkaishi., 62(2): 217-224.

Koochaknejad, E., Ghazilou, A., Ershadifar, H., Kor, K. \& Maghsoudlou, A. 2016. A three-year record of red tides in Chabahar coastal waters (North of Gulf of Oman). J. Persian Gulf, 7(25): 61-66.

Likumahua, S. 2013. Recent blooming of Pyrodinium bahamense var compressum in Ambon Bay, Eastern Indonesia. Mar. Res. Indo., 38 (1):31-37. https://doi.org/10.14203/mri.v38i1.54

Lumapuy, R. 2013. Fitoplankton Penyebab Red Tide di Perairan Teluk Ambon Dalam. Fakultas
Perikanan dan IImu Kelautan, Universitas Pattimura. Ambon.

Padmakumar, K.B., Thomas, L.C., Salini T.C., Vijayan, A. \& Sudhakar, M. 2018. Subsurface bloom of dinoflagellate Gonyaulax polygramma Stein in the shelf waters off Mangalore-South eastern Arabian Sea. Indian J. Mar. Sci., 47(08): 16581664.

Pan, Y., Parsons, M.L., Busman, M., Moeller, P.D.R., Dortch, Q., Powell, C.L. \& Ducette, J. 2001. Pseudo- Nitzschia sp. cf. pseudodelicatissimaa confirmed producer of domoic acid from the northern Gulf of Mexico. Mar. Ecol. Prog. Ser., 220: 83-92. https://doi.org/10.3354/meps220083

Reid, F.M.H., Fuglister, E. \& Jordan J.B. 1970. Phytoplankton taxonomy and standing crop. In: J.D.H. Strickland (Editor). The ecology of the plankton off La Jolla, California, in the period April through September, 1967, Bull. Scripps. Inst. Oceanogr., 17:51-66.

Saputra, F.R.T. \& Lekalette, J.D. 2016. Dinamika massa air di Teluk Ambon. Widyariset. 2(2):143-152. https://doi.org/10.14203/widya riset.2.2.2016.143-152

Sigaud, T.C.S. \& Aidar, E. 1993. Salinity and temperature effects on the growth and chlorophyll-a content of some planktonic algae. Bolm. Inst. Oceanogr., 41(1/2): 95-103. https://doi.org/10.1590/S0373-5524199300 0100008

Smetacek, V. \& Zingone, A. 2013. Green and golden seaweed tides on the rise. Nature, 504: 84-88. https://doi.org/10.1038/nature12860

Sournia, A. 1978. Phytoplankton Manual. UNESCO Press. Paris, France. 337 pp.

Song. J. 2010. Biogeochemical Processes of Biogenic Elements in China Marginal Seas. Zhejiang Univ Press. Hangzhou, China. https://doi.org/10.1007/978-3-642-04060-3

Somsap, N., Gajaseni, N. \& Piumsomboon, A. 2015. Physico-Chemical Factors Influencing Blooms of Chaetoceros spp. and Ceratium furca in the Inner Gulf of Thailand. Agric. Nat. Resour., 49(2): 200-210.

Steidinger, K.A. \& Tangen, K. 1996. Dinoflagellates. In Identifying marine diatoms and dinoflagellates. Tomas CR (Ed), Academic Press, San Diago. 387-584pp. https://doi.org/ 10.1016/B978-012693015-3/50006-1 
Steidinger, K. A., Landsberg, J.H., Tomas, J.H., Tomas, C.R. \& Burns, J. W. 1999. Harmful algal blooms in Florida, Unpublished technical report submitted to the Florida Harmful Algal Bloom Task Force, Florida Marine Research Institute. 1- 63p.

Susilaningsih, D. 2014. Observation, Isolation and Characterization of Microalgal Red Tide Agent Dinoflagellates Prorocentrum sp. IImu Kelautan: Indonesian Journal of Marine Sciences, 19(3): 149-158 doi:10.14710/ ik.ijms.19.3.149-158.

Teichberg, M., Fox, S. E., Olsen Y.S., Valiela I., Martinetto, P., Iribarne O., Muto E.Y., Petti M.A.V., Corbisier T.N., Soto-Jiminez, M., PaezOsuna F., Castro, P., Freitas H., Zitelli A., Cardinaletti M. \& Tagliapietra D. 2010. Eutrophication and macroalgal blooms in temperate and tropical coastal waters: nutrient enrichment experiments with Ulva spp. Glob. Change Biol. 16(9): 2624-2637. https://doi.org/ 10.1111/j.1365-2486.2009.02108.x

Tomas, C.R. 1997. Identifying Marine Phytoplankton. Academic Press. Florida.
Valiela, I., McClelland, J., Hauxwell, J., Behr, P.J., Hersh, D. \& Foreman, K. 1997. Macroalgal blooms in shallow estuaries: controls and ecophysiological and ecosystem consequences. Limnol. Oceanogr. 42:1105-1118. https://doi.org/ 10.4319/lo.1997.42.5_part_2.1105

Van Rijssel, M., Janse, I., Noordkamp, D.J.B. \& Giekes W.W.C. 2000. An inventory of factors that affect polysaccharide production by Phaeocystis globosa. J. Sea Res. 43: 297-306. https://doi.org/10.1016/S1385-1101(00)000 13-7

Wagey, G.A., Wiadnyana, N.N. \& Taylor, F.J.R. 1998. Short note on Alexandrium affine (Inoe and Fukuyo) Balech red tide in Ambon Bay, Indonesia. Seahab 4(2): 1-2.

Wiadnyana, N.N., Sidabutar, T.Matsuoka, K., Ochi, T., Kodama, M. \& Fukuyo, Y. 1996. Note on the occurrence of Pyrodinium bahamense in eastern Indonesian waters. In: Yasumoto, T., Y. Oshima and Y. Fukuyo (eds), Harmful and Toxic Algal Blooms. IOC/UNESCO Paris, pp. 53-56. 